ISSN 1392-3196 / e-ISSN 2335-8947

Zemdirbyste-Agriculture, vol. 106, No. 1 (2019), p. 3-14

DOI 10.13080/z-a.2019.106.001

\title{
Transformations of different soils under natural and anthropogenized land management
}

\author{
Jonas VOLUNGEVIČIUS ${ }^{1}$, Virginijus FEIZA ${ }^{1}$, Kristina AMALEVIČIŪTĖ-VOLUNGE்'1 \\ Inga LIAUDANSKIENE ${ }^{1}$, Alvyra S̆LEPETIENE ${ }^{1}$, Albinas KUNCEVIČIUS ${ }^{2}$, \\ Rokas VENGALIS ${ }^{2}$, Gintautas VÉLIUS ${ }^{2}$, Regina PRAPIESTIENE் ${ }^{2}$, Justina POŠKIENE் ${ }^{2}$ \\ ${ }^{1}$ Institute of Agriculture, Lithuanian Research Centre for Agriculture and Forestry \\ Instituto 1, Akademija, Kèdainiai distr., Lithuania \\ E-mail: jonas.volungevicius@lammc.lt \\ ${ }^{2}$ Vilnius University \\ Universiteto 7, Vilnius, Lithuania
}

\begin{abstract}
The aim of the study is to determine changes in the morphological, physical and chemical properties of soils of Lithuanian agroecosystems caused by their anthropogenic transformation. Summarized data on 33 soil profiles, 5 relatively natural mature forest soils and 28 anthropogenically affected soils, investigated in 2015-2018, are presented. The structure of the soil profile and its variation, the thickness of $\mathrm{Ah}(\mathrm{p})$ horizon, the soil bulk density and total porosity, the soil organic carbon content and its qualitative characteristics in A horizon were examined. The study showed that Retisol $(R T)$ and Planosol $(P L)$ are mostly degraded ex-situ due to the agrogenical effect: disruption of the genetic profile and the removal of the soil organic carbon (SOC) are ongoing, therefore bulk density increases and total porosity decreases. Luvisol (LV), Cambisol (CM) and Gleysol (GL) are most affected by in-situ erosion: soil is compacted and total porosity is decreasing. The loss of SOC due to the removal of biomass contributes to the increase in soil density. The Retisol profile horizons in the upper part are changed from O-Ah-E$\mathrm{E} / \mathrm{B}$ to Ap-E/B. The natural Luvisol profile, described as O-Ah-E-Btg-BCkg, is changed into the sequence of ApAhm-BCk. In archaeological areas, the initial topsoil O-A horizon transformed to a complex cultural layer consisting of terric Ah and buried Ah horizons. When anthropogenic soil Ah soil horizons become deeper (from 10-15 up to $25-30 \mathrm{~cm}$ thick) due to deep ploughing, the E horizon is disturbed and partially mixed and incorporated into Ap horizon. The properties of Ap horizon differ from those of $\mathrm{Ah}$ and $\mathrm{AhE}$ horizons, from which it has developed. The bulk density increases from $0.8-1.08$ to $1.55-1.75 \mathrm{Mg} \mathrm{m}^{-3}$, while the SOC content decreases from $30-40$ to 11-14 $\mathrm{g} \mathrm{kg}^{-1}$ in Ap horizon. Humification degree in the soils of mature forest is amounts to about $25.5 \%$, while in agrogenized soils it varies greatly and amounts about $14 \%$. The most favourable conditions for soil organic matter (SOM) humification and SOC sequestration are in perennial grassland, when biomass is not removed, as well as in mature mixed forests. The ratio of carbon of mobile humic and fulvic acids $\left(\mathrm{C}_{\mathrm{MHA}}: \mathrm{C}_{\mathrm{MFA}}\right)$ varies from 1.02 to 1.54 in relatively natural soils of mature forest, in arable soils varies within the range of $0.58-1.02$, and in meadows $0.91-2.82$, indicating declining SOC sequestration.

In order to solve soil problems related to soil agrogenization, the aspects of SOC content and intensity of land use should be considered. Usage of Luvisol and Cambisol for agriculture, crop rotations must be observed and organic fertilizers must be used in combination with mineral fertilizers. From soil conservation viewpoint, arable farming in Retisol and Planosol should be replaced by grassland and livestock farming.
\end{abstract}

Key words: agricultural land, agrogenic influence on soil profile, archaeological sites, bulk density, humification degree, soil organic carbon.

\section{Introduction}

Soil is a complex system generating a number of interrelated functions and processes. Fertility is one of the basic soil functions related to bio productivity potential, carbon sequestration, physical and chemical soil environment and also it is a space to secure geologically and archeologically Earth history. Soil is a consequence of geo- and agroecological conditions of a landscape.

Soil productivity is related to many other soil features and properties, its profile composition, physical and chemical properties are expression of many processes occurring in the soil.

The identification of soil processes within soil profile of agricultural land is of great importance to reveal soil multifunctional sustainability at present and

Please use the following format when citing the article:

Volungevičius J., Feiza V., Amalevičiūtė-Volungė K., Liaudanskienė I., Šlepetienė A., Kuncevičius A., Vengalis R., Vèlius G., Prapiestienè R., Poškienė J. 2019. Transformations of different soils under natural and anthropogenized land management. Zemdirbyste-Agriculture, 106 (1): 3-14. DOI 10.13080/z-a.2019.106.001 
its use in the past (Walkington, 2010). European scientist Blum and co-workers (2018) have investigated the soil as multifunctional strata. It should be noted that a major challenge for sustainable soil management is to preserve soil multifunctionality for other ecosystem services while optimizing agricultural yields.

From the territorial viewpoint, only a small part of the land (about $3.7 \%$ of soil cover) underwent the urbanization pressure. Most of the soils, about $53 \%$, are transformed agrogenically (Lithuania in Figures, 2017). The soils of archaeological locations are characterised as agrogenically transformed soils, thus agricultural soil scientists (Scudder et al., 1996) investigate them. Only some of these soils demonstrate urbic transformation properties.

The term "agrogenic effect" (agrogenization, agrogenic transformation) summarizes all the impacts on soil related to agricultural activity, without assessing its negative or positive aspects. It is a universal term that defines the impact on soil through the pedogenic prism. Other terms used in scientific literature assess the changes that occur in soil as a result of economic activity, through the prism of the productivity of the soil, and mainly emphasize their negative nature. The term "agrogenic transformation" refers to the general trend of soil development in agroecosystems, in which the main factor is man and his activities, changing the natural processes and determining the accumulation, transfer and output of soil material. The concept of agrogenic effect is part of the concept of anthropogenic transformation of soil, and this term should be used to define the development of soils and the changes in soil properties in agricultural areas.

Agrogenic transformation of soil properties occurring in Lithuania is important in the context of agroecosystem stability and maintenance of soil fertility. Soil agrogenization is related to the transformation of natural properties of background soils, i.e. soils that do not exhibit agrogenic transformation (Kalinina et al., 2013; Nosko, 2013; Novikova, Konyushkova, 2013). According to Veenstra and Burras (2015), in some soils, agrogenic transformations are positive. However, most of them are negative in terms of soil productivity.

The spectrum of research dealing with soil agrogenization issues is very wide. However, the research has been focused primarily on changes in soil organic matter and variation in soil fertility associated with these changes (Ovchinnikova, 2009; 2013; 2016; Kalinina et al., 2010; Lisetskii, Rodionova, 2015). However, the ratio of humic to fulvic acids as well as its change due to the agrogenic transformation of the soil has been little studied, especially in the archaeological sites. According to Vranova et al. (2015), the studies of various organic compounds, such as lipids and proteins, are most emphasized. Meanwhile, the ratio of humic to fulvic acids shows the link between humification and mineralization, as well as the intensity and sustainability of soil use in agriculture. Only a few studies have stressed individual morphological changes in the soil profile. Several researchers have drawn attention to the formation of specific geochemical associations in the soil (Marcinkonis et al., 2004).

Although there is a wide variety of specific research, there are few studies which have summarised and identified explicitly the peculiarities of agrogenic trends on soil formation. Changes in morphological and physical characteristics in profiles of agrogenicallytransformed soils are investigated rarely. Karavaeva
(1996) reported that the content of clay particles and structure of soil aggregates changed, and that this had a negative effect on the soil, but did not identify changes in specific properties, bulk density and field water capacity. Dyck and Kachanoski (2011) investigated the changes in total soil porosity caused by pedogenesis and soil tillage. They determined significant changes in physical soil properties resulting from soil tillage intensity used in agrarian soils as compared with forest soils.

In order to assess the changes in soil properties occurring in agroecosystems, it is important to understand how much soils of agroecosystems have changed in comparison with the background relatively natural soil (Lebedeva et al., 1996; Azaronak, 2005; Volungevicius et al., 2016). Lithuania is located in an area of excessive moisture and mixed forest, so the background of natural soils exists only in mature forests at present. Therefore, the agricultural soil should be considered as soil of forest origin already altered by anthropogenic economic activities in Lithuania. Chendev et al. (2012) expressed a similar approach in soil investigations based on the example of historical development of forested landscapes in the United States and Russia. The research results demonstrated that the long-term tillage strongly modified soil morphology and its chemical and physical properties.

Although the salient changes of agrogenic transformation are recorded in the upper $(0-30-45 \mathrm{~cm})$ layer of the soil profile, Veenstra and Burras (2015) have reported that obvious changes can be recorded even at a depth of 100-150 cm due to the impact of long-term (50 years and more) tillage. Bai et al. (2013) also emphasize the importance of duration of soil cultivation.

When the agrogenic impact on soil is examined, particular attention is given to the adverse changes in soil organic matter. Kalinina et al. (2010) emphasised the changes in ratio of total soil organic carbon (SOC), particulate organic carbon (POC) and soil texture, linking these changes with changes in vegetation, soil nutrient status and soil morphology within soil profile. Aumtong et al. (2009) points out that the nature of landuse and its changes play a significant role in the SOC quantity and quality of the POC. Bai et al. $(2013 ; 2014 ; 2016)$ also examined the changes in soil organic matter and their relationship with different soil tillage.

Breuning-Madsen et al. (2009) compared soil organic carbon stock in ancient and modern land use system. It turned out that it is hardly possible to make a direct comparison because contemporary Ah horizons are under aerobic conditions and ancient ones - under anaerobic. Ovchinnikova $(2009 ; 2013 ; 2016)$ determined that agrogenic transformation of the soil had a negative effect on the quantity and quality of soil humic substances. These studies were carried out on a soddy-podzolic soil, which is one of the predominant soil types in Lithuania, according to system of typological units of soils of 1996 (TDV-96). Lisetskii and Rodionova (2015) considered that soil humus, total nitrogen and carbonate content, as well as structure and water stability of soil aggregates reflect the time, nature and degree of soil agrogenic transformation.

The study has a complex character. Including investigations of the morphology, chemical and physical properties of soil, landscape approach, archaeological data, we attempted to explain the trends of changes in soil forming processes in forestry landscape, archaeological sites and agroecosystems. The findings of these investigations are important not only for Lithuania, 
but also for Europe, because of about $43 \%$ of its territory is attributed to the grassland and cropland.

Approximately 70 years ago, when the political system in the region was changed and the planned economy powered in Lithuania, intensive agriculture began to be used. This system of agriculture had a significant impact on morphology, and chemical and physical properties of the soil. First, these changes were particularly noticeable on the soils of the agroecosystems on hilly moraine uplands. The upper $25-30 \mathrm{~cm}$ depth of A horizon was formed as a result of the use of deep soil ploughing methods; however, an intensive water, wind and mechanical erosion started in soils of arable land. It is noteworthy that soil erosion was not significant until the middle of the $20^{\text {th }}$ century in Lithuania.

In this study, we tested the hypothesis that the intense anthropogenization of soils in the agroecosystems contributes to their degradation.

Methods of pedology are significant to the interpretation of paleosoils' data from archaeological sites. As a result, the reconstruction of paleolandscape and paleogeographical context of archaeological environment can be carried out, as well as the extent of soils' erosion in the past can be estimated. The investigation of soils is important not only for the identified archaeological sites, but also for their surroundings, e.g., the obtained data on agricultural activities would facilitate the disclosure of new prehistoric settlements. In this regard, Lithuanian archaeology is engaged in developing geophysical prospection techniques, geochemical methods, as well as methods of bioarhaeology. The potential of pedology for archaeological interpretation is recognized (Sarcevičius et al., 2016); nevertheless, it is not applied in a considerable extent in Lithuanian archaeology. In archaeological practice, the term "sterile soil" is usually used to describe a stratum with no visual evidence of anthropogenic activity. Traces of tillage are identified only occasionally. Thus methods of pedology should be used as a powerful tool for analysing the archaeological information.
The aim of the study is to determine the changes in the morphological, physical and chemical soil properties of different agroecosystems in Lithuania caused by their anthropogenic transformation.

\section{Materials and methods}

Study area. The study was carried out on relatively natural (mature forest) territory and agrogenically affected areas (arable land). The main agroecosystems are covered, which represent different conditions of terrain and age of the territory (Fig. 1).

As a case study, archaeological sites of Kernave (Širvintos distr.) and Senieji Trakai (Trakai distr.) were selected. Kernavè and its surroundings reflect the main processes of entire Lithuanian prehistory. The continuity of inhabitation evidences that Kernave had been developing into a certain regional centre, which evolved into one of the major political and economic centres of the Grand Duchy of Lithuania in the $13^{\text {th }}-14^{\text {th }}$ centuries. Archaeological finds in the material from Kernave archaeological site testifying agriculture are identified from the $3^{\text {rd }}$ millennium BC (Vengalis, 2017). The archaeological site of Senieji Trakai presents completely different historical situation. At the end of the $13^{\text {th }}$ and beginning of the $14^{\text {th }}$ centuries, formation of the state's new territorial and administrative structure facilitated establishing of castles and settlements in previously unsettled territories. According to the historical data, Senieji Trakai is one of the oldest masonry castles in Lithuania. It was newly built by the dukes from the Gediminaičiai dynasty in the land area, which was covered by forests. The castle and the settlement of Senieji Trakai date back to the very beginning of the $14^{\text {th }}$ century (Baronas et al., 2011; Kuncevičius, 2012).

Summarized data on 33 soil profiles: 5 relatively natural mature forest soils and 28 anthropogenically affected soils (18 agrarian areas and 10 archeological sites), investigated in 2015-2018, are presented in this

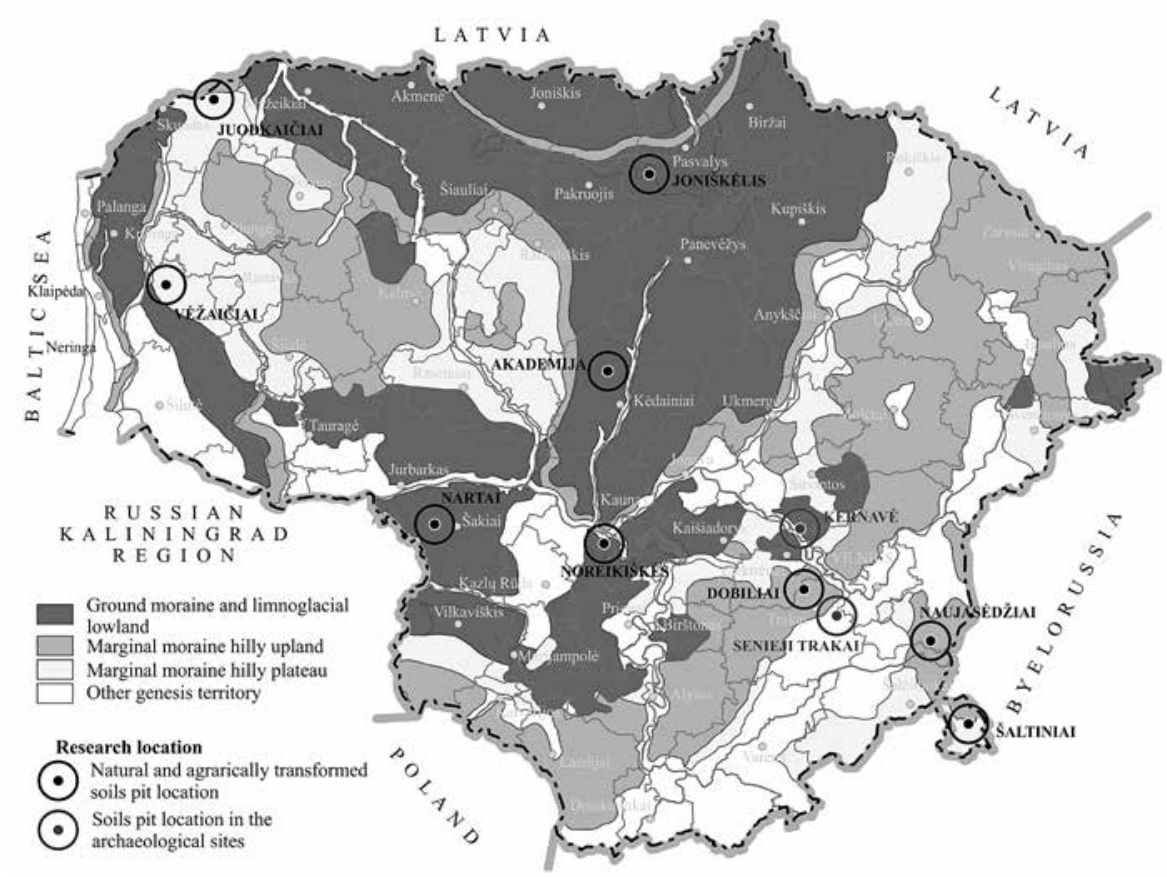

Juodkaičiai - Retisol, Vėžaičiai - Retisol and Luvisol, Joniškèlis - Luvisol and Cambisol, Akademija (Kèdainiai distr.) - Luvisol and Cambisol, Nartai - Luvisol, Noreikiškès - Gleysol and Luvisol, Dobiliai - Retisol, Naujasedžiai and Šaltiniai - Retisol, Senieji Trakai - Arenosol and Anthrosol, Kernavè - Fluvisol and Anthrosol

Figure 1. Geographical location of the research objects 
article. The research objects include the main soils of agroecosystems prevailing in Lithuania: Cambisol (CM), Luvisol (LV), Retisol (RT) and Planosol (PL), and the soils of archeological sites are classified as Arenosol (AR), Fluvisol (FL) and Anthrosol (AT). The aim of the study was to generalize the peculiarities of the anthropogenic transformation of Lithuanian soils; therefore, specific soil typological units will not be emphasized.

Natural and relatively natural (anthropogenically unchanged) zonal soils in Lithuania could be actually found only in mixed forests which are not less than 100 years old. The soil is characterised by $\mathrm{Ah}$ horizon at least $0-16 \mathrm{~cm}$ thick $(10 \mathrm{~cm}$ thick if land has never been ploughed) and well defined eluvial (various E horizons) and illuvial (various B horizons) sections of the profile.

The anthropogenically transformed soils prevail in agrarian and urbanistic landscape of Lithuania (Fig. 1). They are characterised by Ah horizon at least of 25-30 $\mathrm{cm}$ thick, almost indistinct and non-characteristic alluvial (E) and/or illuvial horizons (especially in archaeological sites). Due to intense and long-term use, the soil can completely lose its original natural profile, or can be formed a qualitatively new, completely anthropogenic soil on its surface.

Soil sampling and analysis methods. Different soil profiles were selected in order to reflect the natural soil formation environment and the prevailing anthropogenic effect on soil in agroecosystems. The mature (80-100 years) mixed forest location was chosen to represent relatively natural soil conditions (Luvisol, Retisol and Planosol). Anthropogenically affected soils (the same typological groups as relatively natural selected and additional - Cambisol, Fluvisol and Arenosol) were investigated under semi-natural grassland and in crop rotations of arable land. As the main attributes of soil formation in prevailing Lithuanian soils, for investigation of both natural and anthropogenic activities, the soil profiles were dug to an average depth of 180-200 cm or even deeper down to the ground water level. The morphology of the soil profile was described in detail and the soil typological unit was identified according to the WRB (2014) and Guidelines for soil description and classification (2018). Soil samples for physical and chemical analyses were collected from the genetic horizons of the soil profiles. Undisturbed core samples for determination of soil bulk density and total porosity were collected using stainless steel rings (100 $\mathrm{cm}^{3}$ volumes) in four replications. Bulk density and total porosity were calculated from undisturbed soil samples.

For chemical analyses, the soil samples were air-dried, crushed and sieved through a 2-mm sieve and homogeneously mixed. For the humic substances, soil organic carbon (SOC) analyses, an aliquot of each soil sample was passed through a $0.25-\mathrm{mm}$ sieve. Soil acidity $(\mathrm{pH})$ was determined by potentiometric method in $1 \mathrm{M} \mathrm{KCl}(1: 2.5, \mathrm{w}: \mathrm{v})$. The content of SOC was determined by the Tyurin method, modified by Nikitin (Slepetiene, Butkute, 2003; Vilkiene et al., 2016) with spectrophotometric measure at a wavelength of $590 \mathrm{~nm}$, using dichromate oxidation procedure and glucose as a standard. Dissolved organic carbon (DOC) was measured by IR-detection method after UV-catalysed persulphate oxidation using an ion chromatograph SKALAR (The Netherlands). For the determination of carbon of mobile humic acids $\left(\mathrm{C}_{\mathrm{MHA}}\right)$ and mobile humic substances $\left(\mathrm{C}_{\mathrm{MHS}}\right)$ the extraction procedure was performed using $0.1 \mathrm{M} \mathrm{NaOH}$ solution $(1: 5, \mathrm{w}: \mathrm{v})$. In the broad sense, humification degree shows the relative proportion of soil humic acids carbon, so called "humified carbon", in the total SOC. We established humification degree as a relative proportion of mobile humic acids (MHA) carbon content in the total SOC, expressed in \%.

\section{Results and discussion}

The change in morphology of soil profile. It was revealed that during the agrogenization of the soil, the changes in soil morphology took place throughout the soil profile. Thus, the profile of agrogenicallytransformed soil formed with natural background soil properties in the subsoil and agrarian soil properties in the topsoil (Karavaeva, 2005). However, the most distinct transformations took place in the upper 0-30-40 cm layer of agrogenically affected soils (Volungevicius et al., 2018). Significant changes in the upper layer of the soil profile in archaeological sites are recorded to a depth of 0-60-80 cm (Figs 2 and 5). This shows that during centuries of soil tillage, not only the accumulation of organic matter took place, but also the shift of the arable layer (the horizon Ap) towards declensions of relief, thus forming the colluvium.

In comparison, never-ploughed Ah horizon was only $8-10 \mathrm{~cm}$ thick. This particular thickness of the Ah horizon prevailed in Lithuania until the $13^{\text {th }}-14^{\text {th }}$ centuries, when intensive cultivation of arable farming started (Feiza et al., 2004). However, signs of agriculture in Lithuanian archaeological material are identified from the $3^{\text {rd }}$ millennium BC (Piličiauskas, 2016). Presumably, agriculture was based on the wooden plough (ard) with iron share pulled by horse in the territory of contemporary Lithuania since the $1^{\text {st }}$ century AD. A soil-inverting plough (with a coulter followed by a share to turn up the soil) pulled by oxen was started to use not later than the $12^{\text {th }}$ century (Zulkus, Jarockis, 2013). At the beginning of the $20^{\text {th }}$ century it was ploughed to a depth of $15-18 \mathrm{~cm}$ and, from the middle of $20^{\text {th }}$ century, the thickness of Ap horizon reached $25-30 \mathrm{~cm}$, when mechanized ploughing methods were used. Ap horizon of wet soils (Gleyic Cambisol and Gleysol) can reach 40-50 cm in thickness (Fig. 2).

The results of the investigation showed that when $\mathrm{Ah}(\mathrm{p})$ horizon deepened from 10-15 cm up to 25$30 \mathrm{~cm}$ in thickness due to soil ploughing, the E horizon became disturbed and partially incorporated / mixed into Ap horizon. In the archaeological sites, soil data show that not only $\mathrm{E}$, but also the non-carbonate $\mathrm{B}$ horizon is destroyed due to continuous ploughing. This is evidenced by the carbonate B or BC horizon under the Ah horizon, and can be proved by exhibition of carbonate horizons $\mathrm{B}$ and $\mathrm{BC}$ immediately below soil horizon A. Caused by deep loosening the soil features have been changed. The Ah horizon is replaced by Ap soil horizon. In addition, the $\mathrm{ApE}$ or $\mathrm{ApB}$ horizons are developed. Volungevicius et al. (2018) suggest that due to the long-term practice of deep ploughing and due to soil erosion occurrence, the $\mathrm{E}$ horizon becomes completely destroyed and a sequence of Retisol layers in the upper profile partly changes from $\mathrm{O}-\mathrm{Ah}-\mathrm{E}-\mathrm{E} / \mathrm{B}$ to the Ap-E/B. Similarly, the O horizon is also destroyed. These results are in line with the findings published by Kalinina et al. $(2009 ; 2013)$ that the morphological features of agrogenic effect persist in the soil for over 70 years.

Hydrological changes are a common feature of soils undergoing anthrophological changes. These changes are recorded in all types of soils found in Lithuania (Figs 3 and 4). The reason for this is that land reclamation is one of the widely spread soil fertility improvement measures of agricultural land under water surplus climatic conditions of Nemoral zone. 


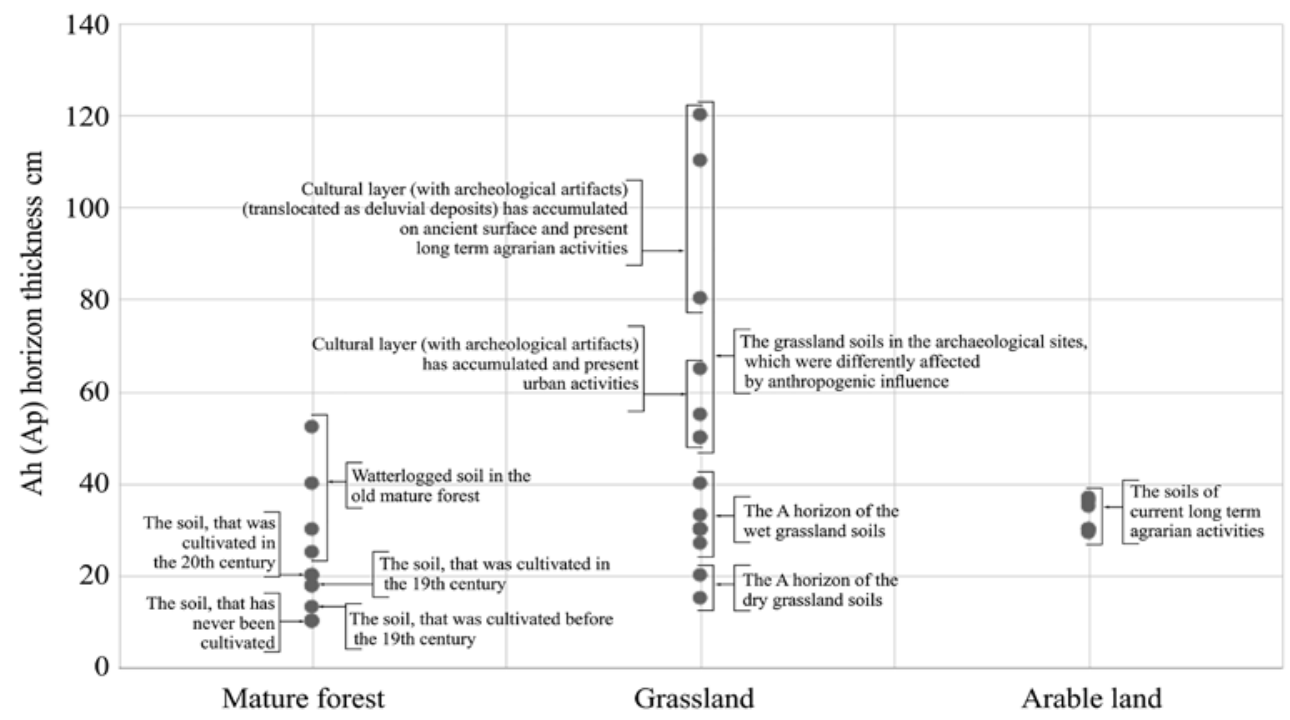

Note. The $\mathrm{Ah}(\mathrm{p})$ horizons were not affected by erosion.

Figure 2. The thickness of Ah horizon in differently used soils in Lithuania
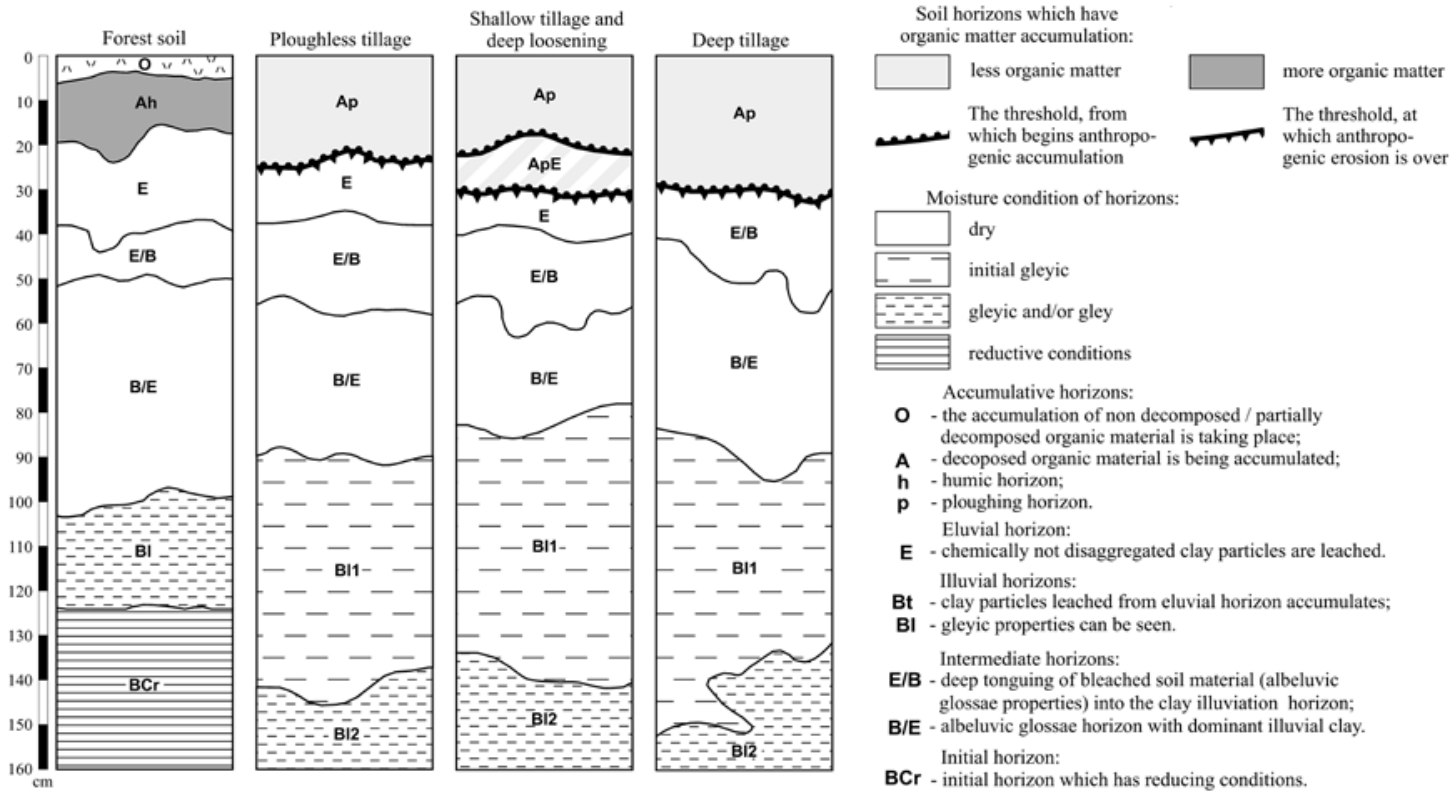

Figure 3. Differences in morphology of agrarian uplands Retisol profiles due to contrasting agrogenic influence
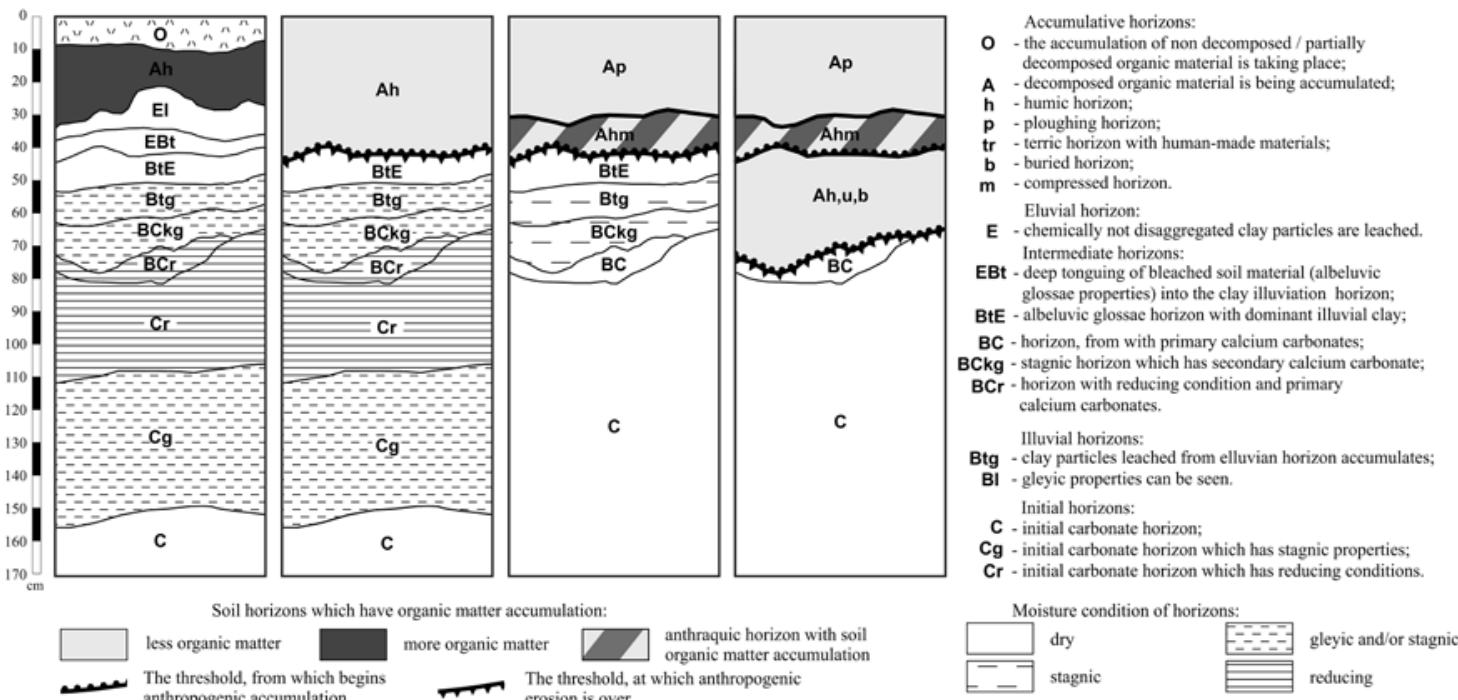

Figure 4. Differences in morphology of agrarian lowlands Luvisol profiles due to contrasting agrogenic influence 
On sloping morainic land, Retisol is a prevailing soil type in Lithuania. These soils are strongly influenced by mechanical soil erosion. This is the reason for structure simplification of soil profile, shallowing top (Ap) horizon, reduction of organic matter in it. Clay textural Luvisol and Cambisol prevailing in lowlands of the country exhibit increasing of soil Ah horizon thickness. It is noteworthy that even several Ah horizons, having contrasting SOC content due to different mineralizationhumification processes, can be registered within top layer of a profile. Even small land surface alteration may have an influence on organic matter changes. Shallow depressions are the zones of SOC accumulation, while small rise is the reason of organic matter reduction and soil bulk density increasing.

Distinctive features of Ap horizons in arable lands, which are located in the territories of archaeological sites (not used for tillage since the second half of the $20^{\text {th }}$ century), are extremely high quantity of SOC (5\%) and their thickness (70-120 $\mathrm{cm}$ and more). Ancient Ah horizons are often covered by colluvial soils (in Kernave, the latter can reach a thickness of 120-160 cm and more). These colluvial soils formed as a result of
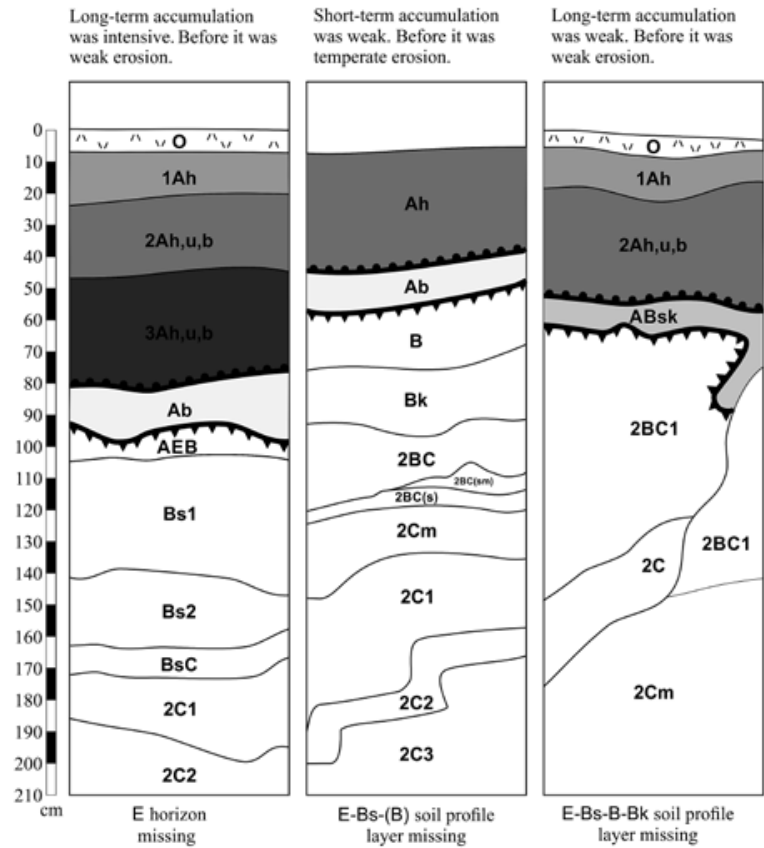

the contemporary agrarian activity. In valleys of rivers, ancient Ah horizons can be covered by Fluvisol, which is under formation.

Soils in archaeological sites have undergone a more complicated development than the soils of the present agrarian territories. The current agrarian practices are only one of the historical stages of soil development in agrarian areas. Meanwhile, even a few stages of agrarian activities are recorded in archaeological sites this is reflected in the profiles of formed soils (Fig. 5). The stages of soil development, human activity, erosion and accumulation are visible in these profiles. The whole soil profile consists of accumulation, eluvial and illuvial parts of the profile. Meanwhile, in Figure 5 these sequences are incomplete. The eluvial (E horizon) and illuvial (B and Bk horizons) parts of profile are missing in the first profile - the destroyed E horizon is indicated by the AEB horizon remaining in its place. This suggests that in this place a settlement and a castle estate were created by disforests, because under Lithuanian climate conditions the soil E horizon can be formed only by forests. Subsequently, this and other soil profile horizons were lost due to excavation or soil tillage.

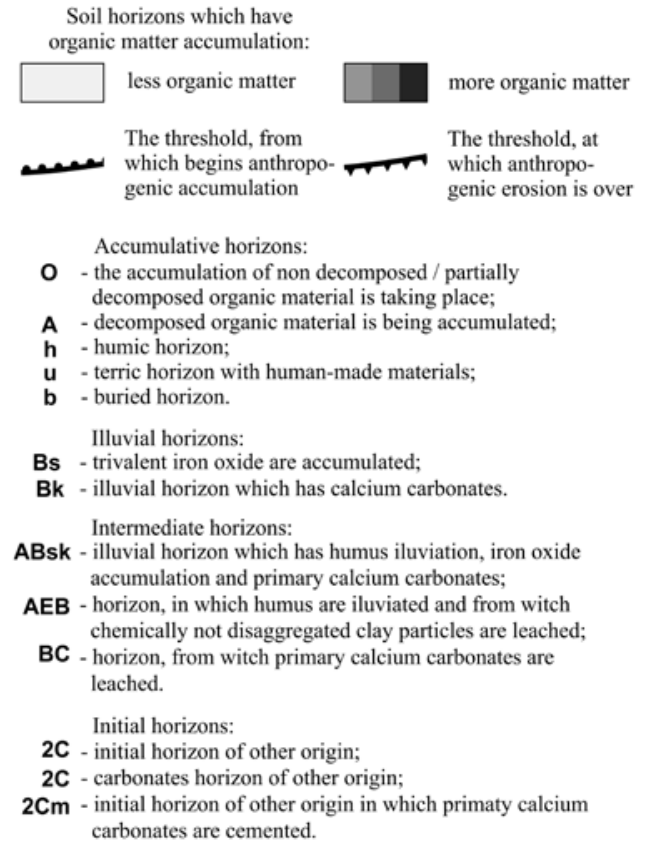

Figure 5. Differences in morphology of soil profiles due to anthropogenic (including agrogenic) influence in grassland of archaeological site of Senieji Trakai, Trakai distr., Lithuania

Renaturalization of soils and formation of $\mathrm{O}$ horizons are under development in the territories of archaeological sites. The processes are determined by the requirements of cultural heritage protection, which are applied to the described sites. At the same time, the transformational character of anthropogenic accumulation of natural soil is preserved. It allows identifying the extent of soils' alteration due to the human agricultural activities in the historical perspective. Accumulation part (Ah, terric and buried $\mathrm{Ah}$ ) of the soil profile is complex, of high thickness and is formed from several horizons. This point to the complex development of this area, as well as long and intense economic activity, which is also associated with soil erosion and colluvial accumulation.

The change in physical properties of agrogenically affected soil profile. Specific characteristics of soil profile morphology are important to soil physical properties and their changes. The processes of soil formation, origin of the parent material, content of soil organic matter and soil tillage determined soil bulk density in the soil profiles studied. Silty loam was typical texture of the Retisol (Vèžaičiai, Klaipèda distr.) investigated. The soil bulk density varied within the range of $1.6-1.8 \mathrm{Mg} \mathrm{m}^{-3}$ in $\mathrm{BCl}$ and $\mathrm{Cl}$ horizons, and this physical soil property was slightly affected, or remained unchanged during soil formation processes.

Chemically disturbed and undisturbed clay particles are transferred from $\mathrm{E}$ horizon during these processes, and accumulate in $\mathrm{E} / \mathrm{B}, \mathrm{B} / \mathrm{E}$ and $\mathrm{Bt}$ horizons. Therefore the soil bulk density was moderate in Bt horizon (about $1.78 \mathrm{Mg} \mathrm{m}^{-3}$ ), somewhat lower in $\mathrm{E} / \mathrm{B}\left(1.62 \mathrm{Mg} \mathrm{m}^{-3}\right.$ ) and $\mathrm{B} / \mathrm{E}$ (about $1.67 \mathrm{Mg} \mathrm{m}^{-3}$ ) horizons, and the lowest bulk density was recorded within El horizon $-1.48 \mathrm{Mg} \mathrm{m}^{-3}$. Presence of organic matter in the Ah (Ap) horizons of the soil profile contributes to the decrease in soil bulk density. It was revealed that the amount of organic matter declined under intensive tillage application, whereas organic matter fractional composition changed due to 
intensive mineralisation, and thus the soil bulk density increased in the Ah (Ap) horizons (Fig. 6).

The variation of the total porosity values within $0-30 \mathrm{~cm}$ soil layer reflects differences in landuse. The highest total porosity was determined in the forest soil

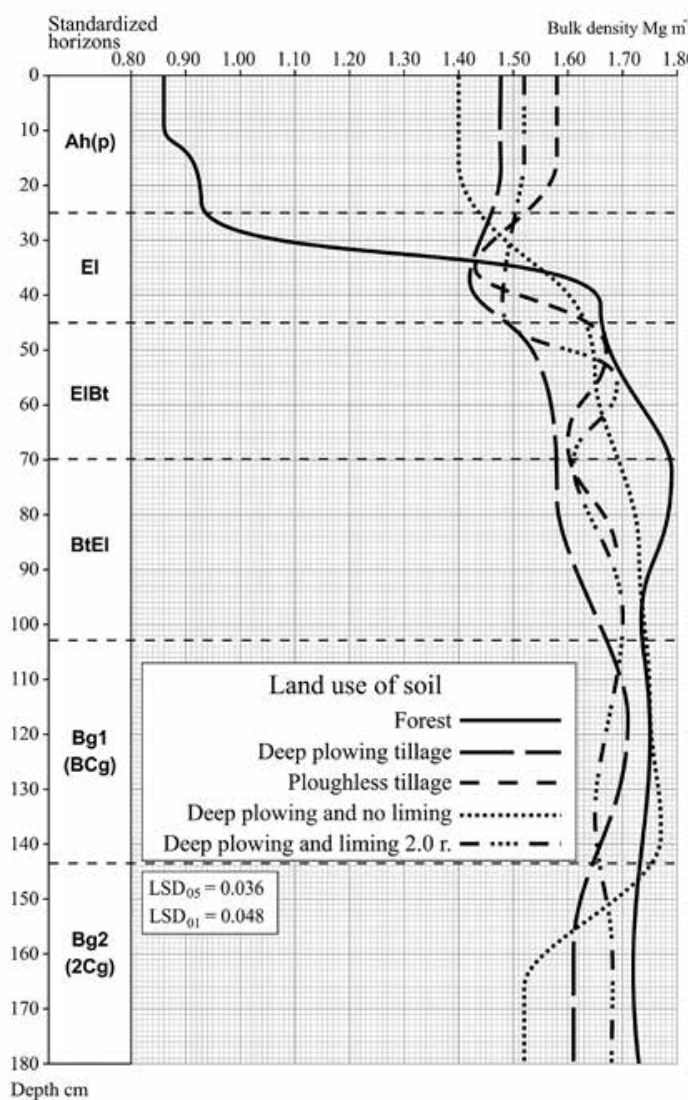

$\left(0.68 \mathrm{~m}^{3} \mathrm{~m}^{-3}\right)$ and the lowest in the ploughless tillage soil $\left(0.40 \mathrm{~m}^{3} \mathrm{~m}^{-3}\right)$ (Fig. 6). The content of organic matter leads to changes in soil bulk density and total porosity in the surface humic ( $\mathrm{Ah} / \mathrm{Ap})$ horizon. As can be seen from the research data, the content of total organic

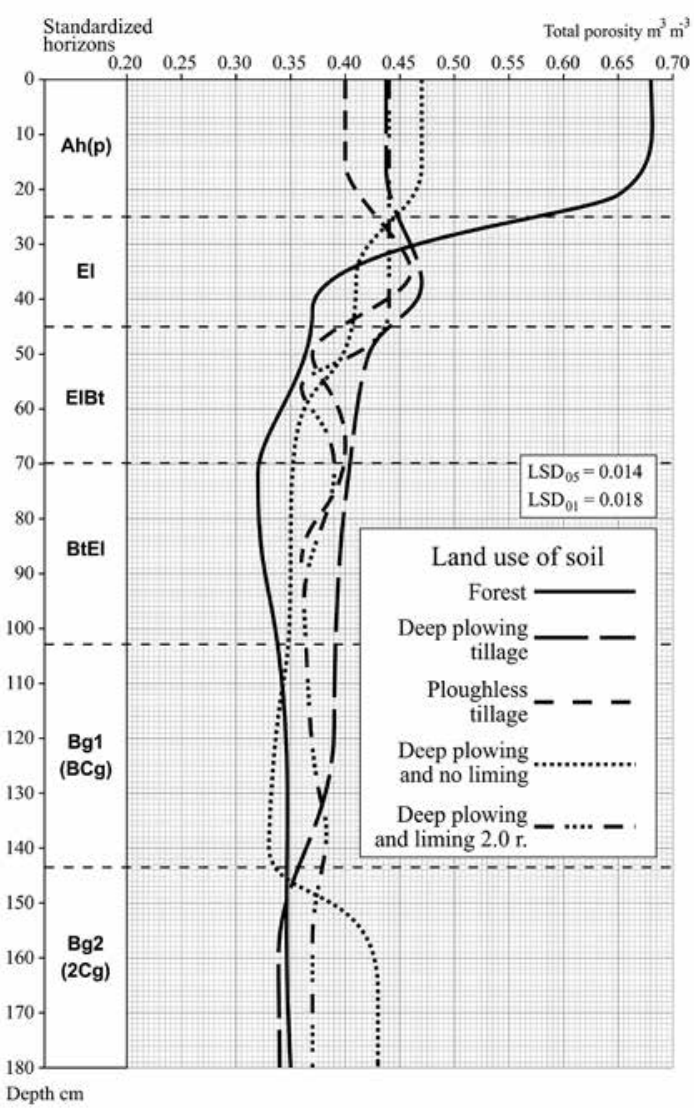

Figure 6. Changes in soil bulk density and total porosity within Retisol profiles under contrasting landuse

carbon was twice $(1.7 \%)$ higher in the surface horizon of forest Retisol compared with that of agrogenically affected soil $(1.0 \%)$. The total porosity in the upper $0-20$ $\mathrm{cm}$ layer of forest soil was determined to be significantly higher compared to that of the agrarian soils (Fig. 6). It was influenced by the amount of SOC in the soil. Eluvial horizon $\mathrm{E}$, the phenomenon of albeluvic glossae and retic properties in the $30-60 \mathrm{~cm}$ soil layer, was closely related to the total porosity. The more processes of podsolization and lessivage occurred in the soil, the higher the total porosity was recorded. The total soil porosity ranged from 0.34 to $0.47 \mathrm{~m}^{3} \mathrm{~m}^{-3}$ in $30-60 \mathrm{~cm}$ soil layer. The soil agrogenization reduced total porosity within the 30-60 $\mathrm{cm}$ layer, especially in El horizon. This occurred because the E horizon had been destroyed by deep ploughing.

The content of SOC as the main component of organic matter decreased and bulk density increased in the $\mathrm{Ah}(\mathrm{p})$ horizon of agrarian soil compared to the forest soil (Table 1). This regularity was noticed in all the cases of $\mathrm{Ah}(\mathrm{p})$ horizon investigation.

Direct relationship within soil profile between bulk density, total porosity and SOC is registered in the case, when the soil has developed from the deposits of homogeneous origin (Table 1, mature forest soil profile).

Table 1. Soil bulk density, total porosity and soil organic carbon (SOC) in the Luvisol profiles under contrasting landuse

\begin{tabular}{|c|c|c|c|c|c|c|c|}
\hline \multicolumn{4}{|c|}{ Arable land - agrogenically affected soil } & \multicolumn{4}{|c|}{ Mature forest - relatively natural soil } \\
\hline $\begin{array}{l}\text { Horizons of } \\
\text { soil profile }\end{array}$ & $\begin{array}{l}\text { bulk density } \\
\qquad \mathrm{Mg} \mathrm{m}^{-3}\end{array}$ & $\begin{array}{l}\text { total } \\
\text { porosity } \\
\mathrm{m}^{3} \mathrm{~m}^{-3}\end{array}$ & $\begin{array}{l}\mathrm{SOC} \\
\mathrm{g} \mathrm{kg}^{-1}\end{array}$ & $\begin{array}{l}\text { Horizons of } \\
\text { soil profile }\end{array}$ & $\begin{array}{c}\text { bulk } \\
\text { density } \\
\mathrm{Mg} \mathrm{m}^{-3}\end{array}$ & $\begin{array}{l}\text { total porosity } \\
\mathrm{m}^{3} \mathrm{~m}^{-3}\end{array}$ & $\begin{array}{l}\text { SOC } \\
\mathrm{g} \mathrm{kg}^{-1}\end{array}$ \\
\hline Ap $(0-30 \mathrm{~cm})$ & 1.75 & 0.340 & 11.6 & $\mathrm{Ah}(0-20 \mathrm{~cm})$ & 1.08 & 0.590 & 31.30 \\
\hline $\operatorname{AE}(30-45 \mathrm{~cm})$ & 1.64 & 0.38 & 9.80 & $\operatorname{AhE}(20-33 \mathrm{~cm})$ & 1.21 & 0.545 & 23.30 \\
\hline $\mathrm{Bt}(45-58 \mathrm{~cm})$ & 1.48 & 0.445 & 3.90 & $\mathrm{E}(33-60 \mathrm{~cm})$ & 1.61 & 0.390 & 9.50 \\
\hline Btl $(58-85 \mathrm{~cm})$ & 1.61 & 0.395 & 2.30 & $\operatorname{Btl}(60-80 \mathrm{~cm})$ & 1.75 & 0.345 & 1.70 \\
\hline $\mathrm{Cl1}(85-105 \mathrm{~cm})$ & 1.77 & 0.330 & 1.30 & & & & 1.20 \\
\hline $\mathrm{Cl} 2(105-120 \mathrm{~cm})$ & 1.90 & 0.280 & 0.60 & 1) & 1.97 & 0. & 1.20 \\
\hline $\mathrm{Cl} 3(120-170 \mathrm{~cm})$ & 1.97 & 0.255 & 1.00 & $\mathrm{Cr}(130-170 \mathrm{~cm})$ & 1.98 & 0.250 & 0.90 \\
\hline \multicolumn{4}{|c|}{$\begin{array}{c}r(\text { soil profile })_{\text {(bulk density/total porosity) }}=-0.999 \\
r(\text { soil profile })_{(\text {SOC/bulk density) }}=-0.338 \\
r(\text { soil profile })_{(\text {SOC/total porosity })}=0.335\end{array}$} & \multicolumn{4}{|c|}{$\begin{array}{c}r(\text { soil profile })_{(\text {bulk density/total porosity) }}=-0.999 \\
r(\text { soil profile })_{(\text {SOC/bulk density })}=0.975 \\
r(\text { soil profile })_{(\text {SOC/total porosity })}=0.971\end{array}$} \\
\hline
\end{tabular}


In that case, a close relationship is recorded; the amount of SOC in soil horizons Ah-AhE has a strong influence on soil bulk density. In the case when the parent material is heterogeneous, when the relationship between SOC and soil physical properties is weak (Table 1, arable land soil profile), this relationship is much influenced by distribution of clay particles within soil profile. In the case of uneven clay content distribution within Ap-AE horizons of soil profile, the amount of SOC significantly correlated with density and total porosity of that soil layer (Table 1, arable land soil profile).
The change in chemical properties of agrogenically affected soil profiles. Change in chemical properties of agrarian soil is one of the key factors for maintaining productivity of agroecosystems and leads to morphological and physical changes in agrogenically affected soil profile. The main chemical properties determining soil fertility, which varies under agrogenization, were soil $\mathrm{pH}$, SOC content and $\mathrm{C}_{\mathrm{MHA}}: \mathrm{C}_{\mathrm{MFA}}$ ratio. Soil agrogenization has a great influence on humification and mineralization processes of soil organic matter (SOM) (Table 2).

Table 2. The chemical properties of Ah horizons of different soils

\begin{tabular}{|c|c|c|c|c|c|c|c|c|c|c|}
\hline \multirow[b]{2}{*}{ Location } & \multicolumn{5}{|c|}{ Relatively natural soils } & \multicolumn{5}{|c|}{ Agrogenically affected soils } \\
\hline & $\mathrm{pH}_{\mathrm{KCl}}$ & $\begin{array}{l}\mathrm{SOC} \\
\mathrm{g} \mathrm{kg}^{-1}\end{array}$ & $\begin{array}{l}\text { DOC } \\
\mathrm{g} \mathrm{kg}^{-1}\end{array}$ & $\begin{array}{c}\mathrm{DOC} \\
\% \text { from } \\
\mathrm{SOC}\end{array}$ & $\begin{array}{l}\text { land } \\
\text { use }\end{array}$ & $\mathrm{pH}_{\mathrm{KCl}}$ & $\begin{array}{l}\mathrm{SOC} \\
\mathrm{g} \mathrm{kg}^{-1}\end{array}$ & $\begin{array}{l}\text { DOC } \\
\mathrm{g} \mathrm{kg}^{-1}\end{array}$ & $\begin{array}{c}\mathrm{DOC} \\
\% \text { from } \\
\mathrm{SOC}\end{array}$ & $\begin{array}{c}\text { land } \\
\text { use }\end{array}$ \\
\hline \multirow{2}{*}{$\begin{array}{l}\text { Akademija, Kèdainiai distr., } \\
\text { Luvisol (MF, G), Cambisol (CT) }\end{array}$} & \multirow{2}{*}{4.11} & \multirow{2}{*}{21.05} & \multirow{2}{*}{0.61} & \multirow{2}{*}{2.89} & \multirow{2}{*}{ MF } & 6.28 & 10.96 & 0.41 & 3.74 & $\mathrm{CT}$ \\
\hline & & & & & & 6.54 & 24.14 & 0.33 & 1.37 & $\mathrm{G}$ \\
\hline $\begin{array}{l}\text { Noreikiškès, Kaunas distr., } \\
\text { Luvisol (MF), Gleysol (CT) }\end{array}$ & 5.86 & 20.01 & 0.29 & 1.45 & MF & 6.66 & 28.36 & 0.29 & 1.02 & CT \\
\hline $\begin{array}{l}\text { Juodkaičiai, Skuodas distr., } \\
\text { Retisol (MF) }\end{array}$ & 3.83 & 19.74 & 0.41 & 2.08 & MF & - & - & - & - & - \\
\hline $\begin{array}{l}\text { Vėžaičiai, Klaipėda distr., } \\
\text { Luvisol (MF), Retisol (CT) }\end{array}$ & 4.54 & 40.42 & 0.61 & 1.51 & MF & 3.49 & 14.22 & 0.20 & 1.41 & CT \\
\hline $\begin{array}{l}\text { Joniškèlis, Pasvalys distr., } \\
\text { Luvisol (MF), Retisol (CT) }\end{array}$ & 5.25 & 31.28 & 0.50 & 1.59 & MF & 6.55 & 11.63 & 0.20 & 1.72 & $\mathrm{CT}$ \\
\hline $\begin{array}{l}\text { Nartai, Šakiai distr., } \\
\text { Luvisol (MF, CT) }\end{array}$ & - & - & - & - & MF & 7.17 & 28.00 & 0.22 & 0.78 & $\mathrm{CT}$ \\
\hline $\begin{array}{l}\text { Šaltiniai, Šalčininkai distr., } \\
\text { Planosol (MF) } \\
\text { Naujasėdžiai, Vilnius distr., } \\
\text { Planosol (G) }\end{array}$ & 5.90 & 59.31 & 0.42 & 0.71 & MF & 5.90 & 26.15 & 0.28 & 1.07 & $\mathrm{G}$ \\
\hline
\end{tabular}

$\mathrm{MF}$ - mature forest, $\mathrm{G}$ - grassland, $\mathrm{CT}$ - conventional tillage; SOC - soil organic carbon, DOC - dissolved organic carbon

The $\mathrm{pH}$ values of Ah horizon of agrogenically affected soils (especially in arable land) are higher $\left(\mathrm{pH}_{\mathrm{KC}}\right.$ 6.28-7.17) compared to relatively natural forest soils, except profiles in Vèžaičiai, Klaipèda district. The data from this site show how strongly the soils of moraine uplands and plateau, predominantly Retisol, with low SOC content under cultivation are acidified. Ploughing, fertilizing and liming of soil caused a decrease in SOC content (Table 2) and introduction of SOC to a deeper soil layer (Fig. 2); however, the Ah horizon grows and various intermediate $\mathrm{A}$ horizons appear. Feiza et al. (2004) have documented that the increasing thickness of Ap horizon did not have noticeable influence on farther soil productivity, if soil became nutrient rich with good physical and hydrological properties. This study showed that SOC content in the Ah horizon of soil profile in the forest was twice or even three times higher, as compared with that of agrogenically affected soils (Table 2 ). The exception was soil in fertilised meadows (Table 2, Kedainiai distr. object), and gleyic and gley soils on arable land (Table 2, Kaunas distr. and Šakiai distr. objects). Although the SOC content distributed more evenly and to a greater depth in agrogenically affected soils, its total amount remained lower than in the conditionally natural forest soil within $10-15 \mathrm{~cm}$ topsoil layer. This trend encourages discussion on the maintenance of agricultural soil fertility and efficiency of improving soil productivity and the selection of soil formation agricultural practices. The total content of SOC is lower in the agrogenically affected soils due to the removal of biomass from the field during harvesting. However, some increase in SOC content in the deeper soil layers is related to its leaching through the eluvial processes. The amount of SOC will preserve and increase, by cultivation of perennial grassland in the agrarian soil.

The degree of SOC sustainability differs according to soil use and this can be seen from the estimated share of DOC in SOC (DOC, \% from SOC). In the analysis of the investigated forest soils, we can see that the forest soil in Kedainiai district (Luvisol) is distinguished not only by DOC, \% from SOC, but also has a highly expressed lessivage process. This process stimulates soil acidification - the established $\mathrm{pH}$ is $4.11 \mathrm{vs}$ 6.28 and 6.54 in agrogenically affected soils, while also promoting the degradation of SOC compounds, which increases the DOC content and DOC, \% from SOC reached 2.89. In other forest soils in Kaunas, Klaipeda and Pasvalys districts (Luvisol), the lessivage process is not very clear, because the El horizon is slightly expressed, and the DOC content is much lower and DOC, \% from SOC ranged from 1.45 to 1.59 , while the lowest DOC, $\%$ from SOC (0.71) was established in forest soil in Vilnius district. This can be explained by the high amount of SOC accumulated in this soil and the dry regime of soil moisture, which causes the soil organic matter (SOM) to be less degradable, dissolved and leached.

The DOC, \% from SOC, varies greatly depending on the soil agrogenization nature in agrogenically affected research sites, not only the measures of agrogenical impact, but also natural environmental factors play an important role here. Low SOC content (only $10.96 \mathrm{~g} \mathrm{~kg}^{-1}$ in Kèdainiai distr.) and, respectively, high DOC value in $\%$ from SOC, show moderate SOC stability and intense mineralization of 
SOM due to continuous tillage. The low value of DOC in $\%$ from SOC of agrogenically affected soil compared to the forest soil can be explained by a relatively low total SOC content or by increased soil humidity regime (gleyic properties in Šakiai distr.), which stimulates decomposition, dissolution and leaching of SOC compounds. The increase in the DOC in \% from SOC, recorded in the Pasvalys district, should be related to the high sorption capacity of the soil, since in the topsoil a large amount of clay particles are accumulated due to geomorphological conditions.

The assessment of the stability of SOM and the quality of the organic acids composing it is rather complicated, as their parameters are determined by many environmental factors and their effects may distort common trends. Under Lithuanian conditions, the $\mathrm{C}_{\mathrm{MH}}: \mathrm{C}_{\mathrm{MFA}}$ ratio is $>1$ in the soils of mixed forests, and the $\mathrm{C}_{\mathrm{MHA}}: \mathrm{C}_{\mathrm{MFA}}$ ratio $<1$ is predominant in intensively cultivated soils, whereas $\mathrm{C}_{\mathrm{MHA}}: \mathrm{C}_{\mathrm{MFA}}$ ratio can reach $>1.5$ in soils of natural and semi-natural meadows. The higher this ratio is the more favourable conditions in the soil for humification processes and SOC sequestration. The higher content of humic acids in the SOM makes it more stable, slows down its mineralization and inhibits soil chemical degradation. It contributes to the preservation of nutrients and macro-elements in the topsoil.

The results obtained during the research do not contradict these provisions, and the emerging discrepancies are explained by the specific conditions of the concrete research site's life. The investigated relatively natural soils were formed under mixed forests dominated by Quercus robur L. and Acer platanoides L., but also contain Picea abies (L.) H. Karst. and Pinus sylvestris $\mathrm{L}$. The $\mathrm{C}_{\mathrm{MH}}: \mathrm{C}_{\mathrm{MFA}}$ ratio was $>1$ and ranged from 1.02 to 1.54 in relatively natural soils under mixed forests in all investigated sites (Table 3 ).

Table 3. The indicators of soil organic matter humification in the soil Ah horizon

\begin{tabular}{|c|c|c|c|c|c|c|}
\hline \multirow{2}{*}{ Location } & \multicolumn{3}{|c|}{ Relatively natural soils } & \multicolumn{3}{|c|}{ Agrogenically affected soils } \\
\hline & $\mathrm{C}_{\mathrm{MHA}}: \mathrm{C}_{\mathrm{MFA}}$ & HD \% & land use & $\mathrm{C}_{\mathrm{MHA}}: \mathrm{C}_{\mathrm{MFA}}$ & $\mathrm{HD} \%$ & land use \\
\hline \multirow{2}{*}{$\begin{array}{l}\text { Akademija, Kèdainiai distr., } \\
\text { Luvisol (MF, G), Cambisol (CT) }\end{array}$} & \multirow{2}{*}{1.54} & \multirow{2}{*}{39.05} & \multirow{2}{*}{ MF } & 1.00 & 10.03 & CT \\
\hline & & & & 0.91 & 6.21 & $\mathrm{G}$ \\
\hline $\begin{array}{l}\text { Noreikiškės, Kaunas distr., } \\
\text { Luvisol (MF), Gleysol (CT) }\end{array}$ & 1.13 & 22.24 & MF & 0.89 & 11.70 & $\mathrm{CT}$ \\
\hline $\begin{array}{l}\text { Juodkaičiai, Skuodas distr., } \\
\text { Retisol (MF) }\end{array}$ & 1.22 & 47.25 & MF & - & - & - \\
\hline $\begin{array}{l}\text { Vėžaičiai, Kaipėda distr., } \\
\text { Luvisol (MF), Retisol (CT) }\end{array}$ & 1.18 & 24.32 & MF & 1.02 & 27.07 & $\mathrm{CT}$ \\
\hline $\begin{array}{l}\text { Joniškèlis, Pasvalys distr., } \\
\text { Luvisol (MF), Cambisol (CT) }\end{array}$ & 1.02 & 26.60 & MF & 0.58 & 10.75 & $\mathrm{CT}$ \\
\hline $\begin{array}{l}\text { Nartai, Šakiai distr., } \\
\text { Luvisol (MF, CT) }\end{array}$ & - & - & MF & 0.71 & 4.61 & $\mathrm{CT}$ \\
\hline $\begin{array}{l}\text { Šaltiniai, Šalčininkai distr., Planosol (MF) } \\
\text { Naujasėdžiai, Vilnius distr., Planosol (G) }\end{array}$ & 1.32 & 16.21 & MF & 2.82 & 33.17 & $\mathrm{G}$ \\
\hline
\end{tabular}

$\mathrm{MF}$ - mature forest, $\mathrm{G}$ - grassland, $\mathrm{CT}$ - conventional tillage; $\mathrm{C}_{\mathrm{MHA}}: \mathrm{C}_{\mathrm{MFA}}-$ ratio of carbon of mobile humic and fulvic acids, $\mathrm{HD}-$ humification degree: the ratio of MHA's carbon to SOC

The lowest $\mathrm{C}_{\mathrm{MHA}}: \mathrm{C}_{\mathrm{MFA}}$ ratio (1.02) was determined in Northern Lithuania, in soil of wet mixed forests in Pasvalys district, dominated by Picea abies, and the highest (1.54) - in the mature leafy forest in the Kedainiai district, where Quercus robur predominates. The results of the study of mobile humic acids show that humification and sequestration of organic carbon occur alongside other soil processes in mature forest soils. The high level of humification is also indicated by the humification degree. Humification degree ranges between $22-39 \%$ in relatively natural soils, the exception is comparatively low humification degree (16.21) of dry mixed forest soil located on the Medininkai highlands (Vilnius distr.), where the Pinus sylvestris predominates (Table 3) and part of the organic matter is not humified, but becomes litter (O horizon) in this forest. Meanwhile, the highest humification degree (39.05) was determined in soil of the mature leafy forest (Kèdainiai distr.) favourable conditions for the humification of organic matter due to the continuous accumulation of $\mathrm{Q}$. robur debris and wet (perudic) moisture regime (Guidelines for soil description, 2006; http://www.fao.org/3/a-a0541e. pdf) in the soil are formed here. The thickness of the Ah horizon indicates that the soil could have been cultivated in this forest for the last time in the $19^{\text {th }}$ century. High humification degree (39.05) and $\mathrm{C}_{\mathrm{MHA}}: \mathrm{C}_{\mathrm{MFA}}$ ratio (1.54) allow assuming that the humification process has not been disturbed and that the soil has not been affected by anthropogenic impact.

The $\mathrm{C}_{\mathrm{MHA}}: \mathrm{C}_{\mathrm{MFA}}$ ratio of agrogenically affected soils is quite diverse, as diverse is the use of the sites under investigation. The $\mathrm{C}_{\mathrm{MHA}}: \mathrm{C}_{\mathrm{MFA}}$ ratio of most soils is $<1$, which indicates that mobile fulvic acids predominate in their organic matter. The investigated sites were under conventional tillage in Kaunas, Pasvalys and Šakiai districts, and organic fertilizers were not used. Sites in Kedainiai and Klaipèda districts were under conventional tillage too; however, the soils were applied with organic fertilizers, so their $\mathrm{C}_{\mathrm{MHA}}: \mathrm{C}_{\mathrm{MFA}}$ ratio is equal to or greater than 1 . The $\mathrm{C}_{\mathrm{MHA}}: \mathrm{C}_{\mathrm{MFA}}$ ratio of perennial grassland in Kedainiai district was 0.91 (Table 3 ) - the grassland was grown only in 2008; therefore, comparing with other agrogenically affected soils, the $\mathrm{C}_{\mathrm{MHA}}: \mathrm{C}_{\mathrm{MFA}}$ ratio is higher (close to 1 ).

Extremely distinctive $\mathrm{C}_{\mathrm{MHA}}: \mathrm{C}_{\mathrm{MFA}}$ ratio was recorded in perennial meadow soil in Naujasedžiai, Vilnius district. This meadow is unused, biomass is not mowed and removed, and here renaturalization has taken place for the last 20 years. This determines the intensive accumulation of organic matter and the process of humification, and the $\mathrm{C}_{\mathrm{MHA}}: \mathrm{C}_{\mathrm{MFA}}$ ratio here is 2.82 . The highest value of humification degree, which reached 33.17 (Table 3), shows a high level of humification. High levels of humification may have been influenced 
by the specific hydrological regime typical of Planosol. The agrogenically affected soil in Klaipeda district is characterized by high humification degree (27.07) this could have happened due to long-term experiments conducted with organic fertilizers here.

Our study demonstrated evidence of soil profile morphological and chemical changes to a depth of 40-50 cm. However, the most distinct transformations took place in the upper $0-30 \mathrm{~cm}$ layer of agrogenically affected soil. On agrarian hummocky land, the main feature of soil profile is morphological changes caused by erosion processes. Soil fertility reduction is closely related to the extent of these changes. Meanwhile, on agrarian lowland, soil physical properties (bulk density, total porosity, etc.) demonstrate the most evident changes taking place in the soil.

The generalization of this research results could be summarized up as follows:

1. When anthropogenic soil Ah soil horizons become deeper (from $10-15 \mathrm{~cm}$ up to $25-30 \mathrm{~cm}$ thick) due to deep soil ploughing application, the E horizon is disturbed and partially mixed and incorporated into Ap horizon.

2. The properties of Ap horizon differ from those of the former horizons (Ah and AhE) from which it has developed. The soil bulk density of the Ap horizon increases approximately twice from $0.8-1.08$ to 1.55 $1.75 \mathrm{Mg} \mathrm{m}^{-3}$, compared to the Ah horizon, while the SOC content decreases two-three times from 30-40 to $11-14 \mathrm{~g} \mathrm{~kg}^{-1}$.

3. Long-term deep ploughing and soil erosion are the basic factors producing the most evident changes in soil Ap layer formation.

4. E horizon and partly the E/B horizon become completely destroyed concerning the sequence profile horizons of Retisol. The sequence of profile horizons in the upper profile are changed from O-Ah-E-E/B to the order of $\mathrm{Ap}-\mathrm{E} / \mathrm{B}(\mathrm{B} / \mathrm{E})$.

5. Similar to Retisol, the order of soil profile horizons of Luvisol also becomes simplified. The most visible changes occur within the top-soil layer. The order of natural soil horizons described as: O-Ah-E$\mathrm{Btl}-\mathrm{BCl}$ is changed in to the sequence of: Ap-Ahm-BC. The horizons lying in the sub-soil area lose their typical gleyic properties. Representative order of horizons $\mathrm{BCr}$ $\mathrm{Cr}$ transforms into the new order of BC-C.

6. In archaeological sites, soils have lost the features of background soil forming due to the use of soil for ages, both for agriculture and habitation, and have become Anthrosol. In their profiles the initial topsoil O-A horizon has transformed into a complex cultural layer consisting of terric Ah and buried Ah horizons. Such sequences of horizons show not only long cultivation of soils, but also their multiplex erosion.

7. Significant transformation patterns were observed in the changes of SOC content of the agrogenically affected soil. The SOC content demonstrated reduction by half as compared to that of the corresponding soil type in the forest: from $20-59$ to $10-26 \mathrm{~g} \mathrm{~kg}^{-1}$.

8. An analysis of soil organic matter humification degree revealed that it is slightly variable in the soils of mature forest and amounts to about $25.5 \%$, which reflects the natural background of humification degree. While in soils of agroecosystems it varies greatly, and amounts to about $14 \%$. Therefore, it is very important to take into account the history of soil use, the duration of renaturalization processes and the use of soil improvers in the past. The research showed that the most favourable conditions for SOM humification and SOC sequestration are in perennial grassland (Planosol), when biomass is not removed, as well as in mature mixed forests (Luvisol). 9. The decline of $\mathrm{C}_{\mathrm{MHA}}: \mathrm{C}_{\mathrm{MFA}}$ ratio and humification degree is a general trend indicating a decrease in soil fertility and the loss of SOM due to mineralization, along with a decrease in SOC sequestration. The $\mathrm{C}_{\mathrm{MHA}}: \mathrm{C}_{\mathrm{MFA}}$ ratio varies from 1.02 to 1.54 in relatively natural Luvisol, Retisol and Planosol of mature forest. Meanwhile, the $\mathrm{C}_{\mathrm{MHA}}: \mathrm{C}_{\mathrm{MFA}}$ ratio in corresponding arable soils varies within the range of $0.58-1.02$, and in meadows $-0.91-2.82$.

10. The decrease of SOC content, indicating soil chemical degradation, plays a key role in agrarian Luvisol and Cambisol. Decline of humification degree and $\mathrm{C}_{\mathrm{MHA}}: \mathrm{C}_{\mathrm{MFA}}$ ratio is a common trend indicating the reduction of soil fertility and the loss of SOM due to mineralization.

\section{Conclusions}

1. Retisol and Planosol, which predominate in agroecosystems of Lithuanian last and penultimate glaciation marginal moraine uplands, are mostly ex situdegraded due to the agrogenical effect, destroying the soil profile and transporting mineral and organic matter, which determines the simplicity of their genetic profile. The increase in bulk density and decrease in total porosity result from a decrease in soil organic carbon (SOC) content. The use of inappropriate agrotechnical measures has led to erosion and to a decrease in soil fertility.

2. Luvisol and Cambisol as well as Gleysol prevailing in agroecosystems of Lithuanian last glaciation, ground moraine lowlands, are most affected by in-situ erosion. It focuses on changes in soil physical and chemical properties, which are influenced by the increase in the intensity of use of soil agrotechnical means. Soil compaction increases and total porosity decreases due to erosion. The loss of SOC due to the removal of biomass contributes to a further increase in soil density.

3. In archaeological sites, Arenosol and Fluvisol have lost their natural properties due to the large accumulated thickness of the Ah horizon (70$200 \mathrm{~cm}$ ) layer over them, and have become Anthrosol thereafter. During the history, Arenosol have undergone initial erosion and subsequent permanent accumulation. Meanwhile, over Fluvisol, from the beginning of their anthropogenization, accumulation processes, which are related to the accumulation of urbic layer and agrariancolluvial processes, began.

4. Applying a different ploughing depth without solving the problem of soil organic matter reduction, does not essentially prevent the increase of soil density, which makes it difficult to achieve an increase in longterm soil fertility.

5. The increase in the thickness of A horizon is one of the most significant positive changes of agrogenical effect in agrarian lands. However, the total SOC content in the soil did not increase with the thickness of this horizon reaching $25-30 \mathrm{~cm}$. In addition, with the exception of perennial grassland, reduction of carbon of mobile humic and fulvic acids ratio $\left(\mathrm{C}_{\mathrm{MHA}}: \mathrm{C}_{\mathrm{MFA}}\right)$ and humification degree occurs in the A horizons of cultivated soils. This leads to a decline in soil organic matter (SOM) quality and a decrease in SOC sequestration rates.

6. As shown by research, in order to solve soil problems related to soil agrogenization, the aspects of SOC content and intensity of land use should be considered, in principle, the aspects of SOC content and soil tillage intensity should be considered essentially. When Luvisol and Cambisol are used for agricultural 
purposes, crop rotations must be strictly observed and organic fertilizers must be used in conjunction with mineral fertilizers. For soil protection reasons, perennial grasslands and livestock farming in Retisol and Planosol should be replaced by arable farming activities.

\section{Acknowledgments}

The part of paper presents research findings from the project "The influence of long-term contrasting intensity resources management on genesis of different soils and on other agro-ecosystems components" (SIT9/2015) funded by the Research Council of Lithuania. The data on archaeological sites is obtained in the framework of the scientific project "Landscape of the Statehood: Environment Transformations in the Historical Capitals of Lithuania" (No. P-MIP-17-181), funded by the Research Council of Lithuania.

Received 27072018 Accepted 09112018

\section{References}

1. Aumtong S., Magid J., Bruum S., Neergaard de A. 2009. Relating soil carbon fractions to land use in sloping uplands in northern Thailand. Agriculture Ecosystems and Environment, 131 (3): 229-239.

https://doi.org/10.1016/j.agee.2009.01.013

2. Azaronak T. 2005. The agrogenic evaluation of soddypodzolic loamy soils of Soligorsk region. Proceedings of the National Academy of Sciences of Belarus, Agrarian Sciences Series, 5: 82-84 (in Russian).

3. Bai J., Xiao R., Zhang K., Gao H., Cui B., Liu X. 2013 Soil organic carbon as affected by land use in young and old reclaimed regions of a coastal estuary wetland, China. Soil Use and Management, 29: 57-64. https://doi.org/10.1111/sum.12021

4. Bai J., Zhao Q., Lu Q., Wang J., Ye X. 2014. Land-use effects on soil carbon and nitrogen in a typical plateau lakeshore wetland of China. Archives of Agronomy and Soil Science, 60 (6): 817-825. https://doi.org/10.1080/03650340.2013.839870

5. Bai J., Zhang G., Lu Q., Jia J., Cui B., Liu X. 2016. Depthdistribution patterns and control of soil organic carbon in coastal salt marshes with different plant covers. Scientific Reports, 6: 34835. https://doi.org/10.1038/srep34835

6. Baronas D., Dubonis A., Petrauskas R. 2011. History of Lithuania. The $13^{\text {th }}$ c. -1385 . Emergence of the State between the East and the West. Vilnius. Lithuania, $616 \mathrm{p}$ (in Lithuanian).

7. Blum W., Schad P., Nortcliff S. 2018. Essentials of soil science. Stuttgard, Germany, $171 \mathrm{p}$.

8. Breuning-Madsen H., Elberling B., Balstroem T., Holst M., Freudenberg M. 2009. A comparison of soil organic carbon stock in ancient and modern land use systems in Denmark. European Journal of Soil Science, 60: 55-63. https://doi.org/10.1111/j.1365-2389.2008.01089.x

9. Chendev Y.G., Burras C. L., Sauer T. J. 2012. Transformation of forest soils in Iowa (United States) under the impact of longterm agricultural development. Eurasian Soil Science, 45 (4): $357-367$.

https://doi.org/10.1134/S1064229312040035

10. Dyck M. F., Kachanoski R. G. 2011. Scale-dependent covariance of soil physical properties above and below a soil horizon interface: pedogenic versus anthropogenic influences on total porosity. Canadian Journal of Soil Science, 91: 149-159. https://doi.org/10.4141/cjss 10078

11. Feiza V., Malinauskas A., Putna J. 2004. Arimo teorija ir praktika. Lithuanian Institute of Agriculture, $220 \mathrm{p}$. (in Lithuanian).

12. Guidelines for soil description and classification: Central and Eastern European. 2018. https://dspace.emu.ee/xmlui/ handle/10492/4243

13. Kalinina O., Goryachkin S. V., Karavaeva N. A., Lyuri D. I., Najdenko L., Giani L. 2009. Self-restoration of post-agrogenic sandy soils in the southern Taiga of Russia: soil development, nutrient status, and carbon dynamics. Geoderma, 152 (1-2): 35-42.

https://doi.org/10.1016/j.geoderma.2009.05.014

14. Kalinina O., Goryachkin S. V., Krause S. E., Lyuri D. I., Giani L. 2010. Chronosequential alterations of properties of post-agrogenic Chernozems of the Kursk steppe zone of Russia under self-restoration. Proceedings of the $19^{\text {th }}$ World Congress of Soil Science, Soil Solutions for a Changing World. Brisbane, Australia, p. 21-24.

15. Kalinina O., Chertov O., Dolgikh A. V., Goryachkin S. V., Lyuri D. I., Vormstein S., Giani L. 2013. Self-restoration of post-agrogenic Albeluvisols: soil development, carbon stocks and dynamics of carbon pools. Geoderma, 207-208: 221-233. https://doi.org/10.1016/j.geoderma.2013.05.019

16. Karavaeva N. A. 1996. Anthropogenic changes of taiga soils on varved clays in Northwest Russia. Eurasian Soil Science, 29 (11): 1201-1209.

17. Karavaeva N. A. 2005. Agrogenic soils: environmental conditions, properties, and processes. Eurasian Soil Science, 38 (12): 1355-1365.

18. Kuncevičius A. 2012. The 1994-1997 and 2009 excavation of the Senieji Trakai castle site. Archaeological investigations in independent Lithuania: 1990-2010. Zabiela G. et al. (eds). Vilnius, Society of the Lithuanian Archaeology, p. 190-195 (in Lithuanian).

19. Lebedeva I. I., Tonkonogov V. D., Shishov L. L., Sukhanov P. A., Pertsovich A. Y. 1996. Agrogenically transformed soils: evolution and taxonomy. Pochvovedenie, 3: 351-358 (in Russian).

20. Lisetskii F. N., Rodionova M. E. 2015. Transformation of dry-steppe soils under long-term agrogenic impacts in the area of ancient Olbia. Eurasian Soil Science, 48 (4): 347 358. https://doi.org/10.1134/S1064229315040055

21. Lithuania in Figures 2017. Statistics Lithuania. https://osp. stat.gov.lt/services-portlet/pub-edition-file?id=26780

22. Marcinkonis S., Karmaza B., Bakšienė E., Končius D., Krištaponyte I., Kupčinskas V., Mašauskas V., Ožeraitienè D., Repšienė R., Tripolskaja L. 2004. Antropogeninè itaka geocheminiam dirvožemiu tipingumui. Žemès ūkio mokslai, 2: 1-10 (in Lithuanian).

23. Nosko B. S. 2013. The formation of the agrogenic typical chernozem profile in the Ukrainian forest-steppe after plowing virgin steppe and fallow soils. Eurasian Soil Science, 46 (3): 325-336.

https://doi.org/10.1134/S1064229313030058

24. Novikova A. F., Konyushkova M. V. 2013. Anthropogenic transformation of soils in the northern Ergeni Upland (studies at the first experimental plot of the Arshan'-Zelmen Research Station). Eurasian Soil Science, 46 (3): 241-253. https://doi.org/10.1134/S106422931303006X

25. Ovchinnikova M. F. 2009. Transformation of humic substances in soddy-podzolic soils under agrogenic impacts. Moscow University Soil Science Bulletin, Russia, 64 (1): 10-16. https://doi.org/10.3103/S0147687409010025

26. Ovchinnikova M. F. 2013. Features of natural stability and agrogenic transformation of soil humus. Eurasian Soil Science, 46 (12): 1150-1163. https://doi.org/10.1134/S1064229313120053

27. Ovchinnikova M. F. 2016. Transformation of humus substances in the long-drained surface-gleyed soddypodzolic soils under conditions of pronounced microrelief and different agrogenic loads. Eurasian Soil Science, 49 (8): 859-867. https://doi.org/10.1134/S106422931608010X

28. Piličiauskas G. 2016. The Lithuanian coast in the subNeolithic and Neolithic. The Beginning of Agriculture. Lithuanian Archaeology, 37: 25-103 (in Lithuanian).

29. Sarcevičius S., Valionienè O., Pugačiauskas V. 2016. The crooked city-castle (Curvum castrum): case study in interdisciplinary research. Institute of Lithuanian History, 288 p. (in Lithuanian)

30. Scudder S. J., Foss J. E., Collins M. E. 1996. Soil science and archaeology. Advances in Agronomy, 57: 1-36. https://doi.org/10.1016/S0065-2113(08)60922-0

31. Slepetiene A., Butkute B. 2003. Use of a multichannel photometer (Multiskan MS) for determination of humic materials in soil after their dichromate oxidation. Analytical and Bioanalytical Chemistry, 375, 1260-1264. https://doi.org/10.1007/s00216-003-1822-4 
32. Veenstra J. J., Burras C. L. 2015. Soil profile transformation after 50 years of agricultural land use. Soil Science Society of America Journal, 79 (4): 1154-1162. https://doi.org/10.2136/sssaj2015.01.0027

33. Vengalis R. 2017. Kernavè in the prehistory of Lithuania. Baltramiejūnaité D. et al. (eds). Discovered Kernave: archaeological site museum catalogue. Administration of the state cultural reserve of Kernave, p. 52-61 (in Lithuanian).

34. Vilkiene M., Ambrazaitiene D., Karcauskienè D., Dabkevicius Z. 2016. Assessment of soil organic matter mineralization under various management practices. Acta Agriculturae Scandinavica, Section B: Soil and Plant Science, 66 (8): 1-6. https://doi.org/10.1080/09064710.2016.1162845

35. Volungevicius J., Jukna L., Veteikis D., Vaisvalavicius R., Amaleviciute K., Slepetiene A., Skorupskas R., Jankauskaite M. 2016. The problem of soil interpretation according to the WRB 2014 classification system in the context of anthropogenic transformations. Acta Agriculturae Scandinavica, Section B: Soil and Plant Science, 66 (5): 452-460.

https://doi.org/10.1080/09064710.2016.1164231
36. Volungevicius J., Amaleviciute K., Feiziene D., Feiza V., Slepetiene A., Liaudanskienè I., Versuliene A. Vaisvalavicius R. 2018. The effects of agrogenic transformation on soil profile morphology, organic carbon and physicochemical properties in Retisols of Western Lithuania. Archives of Agronomy and Soil Science, 64 (13): 1910-1923.

https://doi.org/10.1080/03650340.2018.1467006

37. Vranova V., Marfo T. D., Rejšek K. 2015. Soil scientific research methods used in archaeology - promising soil biochemistry: a mini-review. Acta Universitatis Agriculturae et Silviculturea Mendelianae Brunensis, 63: 1417-1426. https://doi.org/10.11118/actaun201563041417

38. Walkington H. 2010. Soil science applications in archaeological contexts: a review of key challenges. EarthScience Reviews, 103 (3-4): 122-134. https://doi.org/10.1016/j.earscirev.2010.09.002

39. WRB. 2014. World reference base for soil resources. World Soil Resources Reports No. 106. FAO, Rome, $192 \mathrm{p}$

40. Žulkus V., Jarockis R. 2013. Vikingų laikai ir ikivalstybinis laikotarpis (Lietuvos archeologija, IV tomas). Klaipėda, Lithuania, 358 p. (in Lithuanian).

ISSN 1392-3196 / e-ISSN 2335-8947

Zemdirbyste-Agriculture, vol. 106, No. 1 (2019), p. 3-14

DOI 10.13080/z-a.2019.106.001

\title{
Skirtingų dirvožemių transformacijos natūraliose ir antropogenizuotose žemėnaudose
}

\author{
J. Volungevičius ${ }^{1}$, V. Feiza ${ }^{1}$, K. Amalevičiūtè-Volungè ${ }^{1}$, I. Liaudanskiené ${ }^{1}$, A. Šlepetiené ${ }^{1}$, \\ A. Kuncevičius², R. Vengalis², G. Vèlius², R. Prapiestiené², J. Poškienè ${ }^{2}$ \\ ${ }^{1}$ Lietuvos agrarinių ir miškų mokslų centro Žemdirbystės institutas \\ ${ }^{2}$ Vilniaus universitetas
}

\section{Santrauka}

Tyrimo tikslas - nustatyti Lietuvos agroekosistemu dirvožemiuose dèl jų antropogeninès transformacijos vykstančius profilio morfologinių, fizikinių ir cheminių savybių pagrindinius pokyčius. Tyrimas atliktas 20152018 metais. Straipsnyje apibendrinti dirvožemio 33 profilių duomenys: 5 sąlygiškai natūralių brandaus miško dirvožemių ir 28 antropogenizuotų ariamų laukų bei pievų dirvožemių. Tirta dirvožemio profilio struktūra ir jo kaita, $\mathrm{Ah}(\mathrm{p})$ horizonto storis, jame esančių organinès ir vandenyje tirpios organinès anglies kiekiai, judriuju huminių ir fulvinių rūgščių santykis, humifikacijos laipsnis, dirvožemio tankis ir suminis poringumas.

Tyrimo duomenimis, dẻl žemès ūkio veiklos balkšvažemis ir palvažemis dažniausiai patiria eroziją ex situ: vyksta genetinio profilio ardymas ir dirvožemio organinès anglies kiekio mažèjimas. Dèl to didejja dirvožemio tankis ir mažèja suminis poringumas. Išplautžemis, rudžemis ir šlynžemis labiausiai yra veikiami erozijos in situ: vyksta dirvos suslègimas ir suminio poringumo mažejimas. Dirvožemio organinès anglies netenkama dèl derliaus (biomasès) išvežimo, o tai didina dirvožemio tankị. Sąlygiškai natūralaus balkšvažemio profilio viršutinė dalis kinta iš $\mathrm{O}-\mathrm{Ah}-\mathrm{E}-\mathrm{E} / \mathrm{B}$ i $\mathrm{Ap}-\mathrm{E} / \mathrm{B}(\mathrm{B} / \mathrm{E})$, o išplautžemio profilis $\mathrm{O}-\mathrm{Ah}-\mathrm{E}-\mathrm{Btl}-\mathrm{BCl}$ - i Ap-Ahm-BC. Archeologinėse vietovėse dirvožemio pirminis sluoksnis O-A yra keičiamas ị sudètingą kultūrinị sluoksnị, sudarytą iš trąšažeminio Ah ir palaidotu Ah horizontų. Dèl gilaus arimo agrarinių teritorijų dirvožemio Ah horizontas storejja (nuo 10-15 iki $25-30 \mathrm{~cm}$ ). I jo sudèti patenka giliau esantis El horizontas ir suformuojamas Ap horizontas. Ap horizonto savybès skiriasi nuo Ah ir AhE horizontu, iš kuriu jis buvo suformuotas, savybiù. Ap horizonto tankis didèja nuo $0,8-1,08$ iki 1,55-1,75 $\mathrm{Mg} \mathrm{m}^{-3}$, o dirvožemio organinès anglies kiekis mažeja nuo $30-40$ iki $11-14 \mathrm{~g} \mathrm{~kg}^{-1}$. Santykinai natūralaus brandaus miško dirvožemio humifikacijos laipsnis siekia vidutiniškai $25,5 \%$, o agrariniu teritorijų dirvožemių jis yra vidutiniškai $14 \%$. Dirvožemio organinès medžiagos humifikacijai ir organinęs anglies kaupimuisi palankiausios sąlygos yra renatūralizuotose pievose, iš kurių biomasè nèra išvežama, taip pat brandžiuose mišriuosiuose miškuose. Judriųjų huminių ir fulvinių rūgščių anglies santykis (angl. $\mathrm{C}_{\mathrm{MHA}}: \mathrm{C}_{\mathrm{MFA}}$ ) brandaus miško dirvožemių svyruoja nuo 1,02 iki 1,54 , ariamų dirvožemių kinta nuo 0,58 iki 1,02 , pievų - nuo 0,91 iki 2,82. Tai rodo organinès anglies kaupimosi mažejimą agrarinėse teritorijose.

Siekiant spręsti su dirvožemio agrogenizacija susijusias problemas, turi būti sprendžiami dirvožemio organinès anglies kiekio ir dirvožemio naudojimo intensyvumo klausimai. Žemės ūkyje dirbant išplautžemius ir rudžemius, turi būti laikomasi sejjomainų, kartu su mineralinèmis trąšomis reikia naudoti organines trąšas. Dirbant balkšvažemius ir palvažemius, dirvosauginiu atžvilgiu ariminė žemdirbystė juose turi būti keičiama ị žolininkystę ir gyvulininkystę.

Reikšminiai žodžiai: agrogeninis poveikis dirvožemio profiliui, archeologinè vietovė, dirvožemio organinè anglis, dirvožemio tankis, humifikacijos laipsnis, žemès ūkio teritorija. 